\title{
しょら油の購入と消費動向に関する実態調査結果
}

消費動向は, メーカーにとって最大の関心事である。本稿は, モニタ

一調査の集計結果であるが，これをみると地域にもよるが，購入の動機

一つを取ってみても以前とは大分違った動きが見受けられる。今後の販

売戦略の資料として活用いただければ幸いである。

新井昇

昭和 51 年から醬油業界では, 全国から約 500 名のし ょら油モニターを設置し, 毎年 1 回しょら油に関する実 態調查を行ってきたが, 今回との第 6 回のしょら油に関 するモニター調査の結果をまとめることができた。

今回の調查内容は主として, I . しょら油の購入先, II. しょら油の購入価格と消費量，III. しょら油購入の 際の避択基準， N. しょら油の消費量の動向等を中心に 行った。

[調査方法]

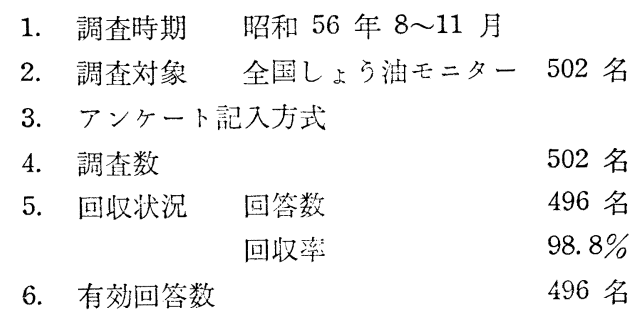
[調査結果内容]（以下のとおり）

\section{I. しょう油の購入先について}

\section{1. 購入先}

(カッコ内 \% は, 第 1 回モニター調査 $<$ 昭和 $51>$ に よるものである。)

全体として，しょら油を購入する先は第 1 表に示すよ らに「スーパー」からが一番多く $32.1 \%(24.5 \%)$,「酒 販店」からが $16.6 \%(26.8 \%)$, 「食料品店」からが $15.5 \%(17.7 \%)$, 「生協」3.6\% (5.8\%) となってい る。「その他」 $29.4 \%$ の中に含まれている「しょら油製 造元から購入する」は $21.5 \%$ である。このほかの「そ の他）のしょら油購入先は, 米屋, 共同購入, デパー 卜, 魚屋, 農業高校, 婦人会等となっている。6 年前に 第 1 回の購入調査の時と比べてみると「スーパー」から の購入は増加しており,「酒販店」,「食料品店」からの購 入は減少している。
〔年令別】にみると，年令が低くなるほど「スーパー」 からの購入比率が高くなっている。またとくに 20 代で 「酒徥店」「食料品店」からの購入が少ないのが目立って いる。

〔地域別〕にみると, 第 2 表に示すように, 「スーパ 一」からの購入比率が 高いのは関東地区, 「酒販店」か らの購入が多いのは近幾地区となっている。「食料品店」 からの購入については，北海道・東北と四国地区に多 い。な新，「その他」の中の「しょう油製造元からの購 入」は中国, 九州地区が多い。

\section{2. 購入理由}

全体として，購入理由をみると，第 3 表に示すように 「地理的に便利だから」が $34.5 \%$ と一番多く,「顏なじ みだから」が $29 \%$ ，「配達をしてくれるから」が 28.8

第 1 表しょう油の購入先調査

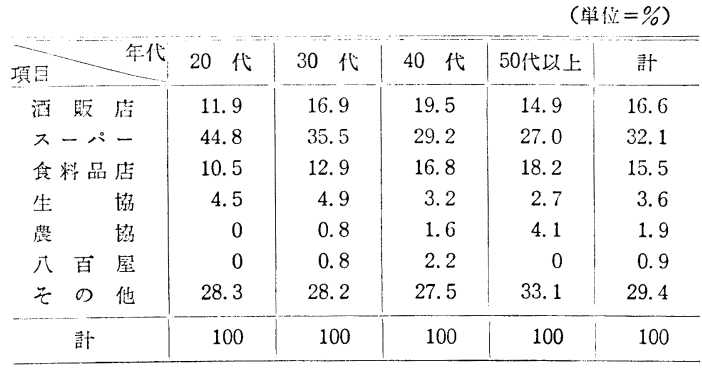

第 2 表 地域別購入先

\begin{tabular}{|c|c|c|c|c|c|c|c|c|c|c|}
\hline & & & & & & & & & （単位 & $\%)$ \\
\hline 項 目 & 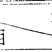 & 地 & 北海道 & 関東 & $\begin{array}{l}\text { 東海 } \\
\text { 北陸 }\end{array}$ & 近畿 & 中国 & 四国 & 九州 & 計 \\
\hline 酒 & 販 & & 6.8 & 14.4 & 23.8 & 46.4 & 8.2 & 8.5 & 6.0 & 16.6 \\
\hline$\pi$ & - & - & 35.1 & 50.0 & 32.1 & 18.9 & 12.2 & 31.9 & 26.5 & 32.1 \\
\hline 食 & 粉品 & 店 & 21.6 & 15.3 & 11.9 & 5.8 & 16.3 & 23.4 & 16.9 & 15.4 \\
\hline 生 & & 㙝 & 5.4 & 5.1 & 2.4 & 1.4 & 0 & 2.1 & 6.0 & 3.6 \\
\hline 宸 & & & 1.4 & 0.8 & 1.2 & 1.4 & 6.1 & 6.4 & 0 & 1.9 \\
\hline 八 & 百 & & 1.4 & 0 & 0 & 5.8 & 0 & 0 & 0 & 1.0 \\
\hline そ & の & 他 & 28.3 & 14.4 & 28.6 & 20.3 & 57.2 & 27.7 & 44.6 & 29.4 \\
\hline & 部 & & 100 & 100 & 100 & 100 & 100 & $1 \mathrm{CO}$ & 100 & 100 \\
\hline
\end{tabular}


第3 表 購 入 理 由

(単位 $=\%)$

\begin{tabular}{|c|c|c|c|c|c|}
\hline 年代 & 20 代 & 30 代 & 40 代 & 50 代以上 & 計 \\
\hline 地理的に便利 & 43.3 & 34.8 & 33.7 & 30.9 & 34.5 \\
\hline 顔なじみ & 19.4 & 25.4 & 33.1 & 31.7 & 29.0 \\
\hline 配達をしてくれる & 19.4 & 27.1 & 30.2 & 33.1 & 28.8 \\
\hline 価格が安い & 23.9 & 31.4 & 27.3 & 25.9 & 27.4 \\
\hline 品揃えが豊富 & 14.9 & 16.1 & 16.9 & 18.0 & 16.7 \\
\hline その他 & 11.9 & 10.2 & 11.1 & 10.1 & 10.7 \\
\hline
\end{tabular}

（注）重複回答のため合計は100\%にならない。

第 4 表 地域的にみた購入理由

（単位 $=\%)$

\begin{tabular}{|c|c|c|c|c|c|c|c|c|}
\hline 項目 & $\begin{array}{l}\text { 北海道 } \\
\text { 北 }\end{array}$ & 関東 & $\begin{array}{l}\text { 東海 } \\
\text { 北陸 }\end{array}$ & 近幾 & 中国 & 四国 & 九州 & 計 \\
\hline 地理的に便利 & 33.3 & 38.0 & 31.2 & 31.9 & 28.0 & 33.3 & 41.0 & 34.5 \\
\hline 顔なじ & 6.1 & 19.4 & 27.3 & 7 & 22.0 & 40.0 & 37.2 & 29.0 \\
\hline 配達をしてくれる & 21.7 & 19.4 & 35.1 & 36.2 & 40.0 & 13.3 & 37.2 & 28.8 \\
\hline 価格が安し & 31.9 & 41.7 & 29.9 & 15.9 & 18.0 & 17.8 & 23.1 & 27.4 \\
\hline 品揃关 & 21.7 & 11.1 & 15.6 & 17.4 & 8.0 & 33.3 & 16. 7 & 16.7 \\
\hline その他 & 11.6 & 11.1 & 13.0 & 7.3 & 10.0 & 8.9 & 11.5 & 10. \\
\hline
\end{tabular}

（注）重複回答のため会計は $100 \%$ にならない。

第 5 表 購入時 の 状態

(単位 $=\%)$

\begin{tabular}{|c|c|c|c|c|c|}
\hline 年代項 目 & 20 代 & 30 代 & 40 代 & $\begin{array}{l}50 \text { 代 } \\
\text { 以上 }\end{array}$ & 計 \\
\hline しょう油がなくなった時 & 16.2 & 8.8 & 14.1 & 12.1 & 12.5 \\
\hline しょう油が少なくなった時 & 52.7 & 61.0 & 60.0 & 59.2 & 59.0 \\
\hline 他のものと一緒に買う & 8.1 & 5.1 & 3.2 & 3.2 & 4.4 \\
\hline 定期的に買 & 4.1 & 7.4 & 8.1 & 8.9 & 7.6 \\
\hline 特売している時に買う & 18.9 & 17.7 & 13.5 & 14.0 & 15.4 \\
\hline その他 & 0 & 0 & 1.1 & 2.6 & 1.1 \\
\hline${ }_{1}$ & 100 & 100 & 100 & 100 & 100 \\
\hline
\end{tabular}

\%,「洒格が安いから」が $27.4 \%$ ，「品揃光が豊富だか ら」が $16.7 \%$ となっている。

なお，「スーパー」から購入している人を妨き出して 調べてみると，「価格が安いから」「地理的に便利だか ら」「品揄党が豊富だから」の順となっており,「酒販 店」から購入している人は「配達をしてくれるから」 「顔なじみ」「地理的に便利だから」の順になっている。

〔年代別〕にみると，「価格が安いから」といら理由は 年令に全く閔係がないようである。「価格が安いから」 以外の理由について，20 代だけが他の年代と違う傾向 をもち，「地理的に便利」が多く、「顔なじみだから」「配 達をしてくれるから」が少ない。

〔地域別】にみると第 4 表に示すように, 購入先のパ ターンがはっきりみ兄る。スーパー購入型の北海道・東 北, 関東地区は，「地理的に便利たから」と「価格が安い から」が多く, 酒販店購入型の 近幾地区は「地理的に 便利だから」「顔なじみだから」「配達をしてくれるか ら」が多く, 食料品店購入型の四国地区は「地理的に便 利だから」「品揃点が豊富だから」「顔なじみだから」が 多い。「その他」の中の「しょう油製造元から購入」して
第 5 表 地域的にみた購入時の状態

(単位 $=\%$ )

\begin{tabular}{|c|c|c|c|c|c|c|c|c|}
\hline 項 & $\begin{array}{l}\text { 北海 } \\
\text { 道北 }\end{array}$ & 関東 & $\begin{array}{l}\text { 東海 } \\
\text { 北陸 }\end{array}$ & 近畿 & 中国 & 四国 & 九州 & 計 \\
\hline しょう油がなくなった時 & 15.8 & 7.4 & 9.1 & 17.3 & 19.2 & 10.0 & 13.5 & 12.5 \\
\hline 少なくなった時 & 59.2 & 53.2 & 62.5 & 58.7 & 57.7 & 72.0 & 57.2 & 59.1 \\
\hline 他のものと一緒に買う & 3.9 & 6.6 & 2.3 & 5.3 & 5.8 & 0 & 4.5 & 4.4 \\
\hline 定期的に買 5 & 6.6 & 6.6 & 6.8 & 4. 0 & 13.5 & 4. 0 & 12.4 & 7.6 \\
\hline 特売している時に & 14.5 & 24.6 & 15.9 & 14.7 & 1.9 & 14. 0 & 12.4 & 15.4 \\
\hline その 他 & 0 & 1.6 & 3.4 & 0 & 1.9 & 0 & 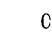 & 1.1 \\
\hline & 100 & 100 & 100 & 100 & 100 & 100 & 100 & 100 \\
\hline
\end{tabular}

いるのは中国，九州地区に多く，その理由は「地理的に 便利だから」「顔なじみだから」配達をしてくれるか ら」となっている。

\section{3. 購入時の状態}

購入時の状態については第 5 表に示すように全体とし ては,「しょう油が少なくなった時」に購入する場合が一 番多く $59 \%$,「特売している時」購入するのが $15.4 \%$, 「しょう油がなくなった時」購入するのが $12.5 \%$,「定期 的に買ら」のが $7.6 \%$,「他のものと一緒に買ら」のが $4.4 \%$,「その他」が $1.1 \%$ の順となっている。

また,「スーパー」から購入する時の状態は,「特売し ている時」に購入するが比較的多くなっているのが特徴 である。

〔年代別】でみると，「しょう油が少なくなった時」購 入するのは 20 代が多い。また「特売している時」購入 するのは 20 代, 30 代でやや多い。

〔地域別】にみると第 6 表に示すよらに，「特売してい る時」購入するのは, 関東地区が極めて多く，4 人に 1 人の割合いとなっている。また「定期的に買う」のは， しょら油製造元から購入する人の多い中国，九州地区で ある。

\section{II. 購入価格と消費量}

\section{1. 購入価格}

購入したしょう油の品質について特定していないため, 高価格品, 低価格品とさまざまであろらが, 購入価格に ついては第 7 表に示すよらに 1 リットル当りの購入価格 は全体としては，241 円から 270 円までが一番多く 23 \%を占めている。次多いのが 211 円から 240 円まで (15.3\%) と，181 円から 210 円まで (14.2\%), 271 円 から 300 円まで $(13.7 \%)$ となっている。

〔年代別〕にみると，いずれの年代も最も購入比率の 多い価格帯は, 241 円から 270 円である。しかし, 安い 価格で購入しているのは 20 代, 30 代に多く, 40 代, 50 代の購入価格は高くなっている。240 円以下で購入し ている人は 20 代で $41.2 \% ， 30$ 代で $39.6 \%$ あるのに 対して，50 代の人は $28.5 \%$ である。また， 300 円以上 
第7表 購 入 価 格

\begin{tabular}{|c|c|c|c|c|c|}
\hline & & & & \multicolumn{2}{|c|}{ (単位 $=\%)$} \\
\hline 項 目 年 代 & 20 代 & 30 代 & 40 代 & $\begin{array}{l}50 \text { 代 } \\
\text { 以上 }\end{array}$ & 計 \\
\hline 150 円以下 & 4.4 & 2.5 & 0.6 & 0 & 1.4 \\
\hline 151 180 円 & 7.4 & 7.6 & 5.1 & 2.1 & 5.1 \\
\hline $181 \sim 210$ & 13.2 & 16.0 & 16.8 & 10.4 & 14.3 \\
\hline $211 \sim 240$ & 16.2 & 13.5 & 15.7 & 16.0 & 15.3 \\
\hline $241 \sim 270$ & 22.1 & 27.7 & 20.8 & 22.2 & 23.0 \\
\hline $271 \sim 300$ & 16.2 & 12.6 & 12.9 & 14.6 & 13.7 \\
\hline $301 \sim 350$ & 5.9 & 1.7 & 8.4 & 13.2 & 7.9 \\
\hline $351 \sim 400$ & 4.4 & 6.7 & 5.6 & 10.4 & 7.1 \\
\hline 401 円以上 & 2.9 & 4.2 & 7.9 & 7.6 & 6.3 \\
\hline 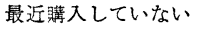 & 7.3 & 7.6 & 6.2 & 3.5 & 5.9 \\
\hline 計 & 100 & 100 & 100 & 100 & 000 \\
\hline
\end{tabular}

第 8 表 地域別にみた購入価格

(単位 $=\%$ )

\begin{tabular}{|c|c|c|c|c|c|c|c|c|}
\hline 項 目 地 域 & 北海道 & 関東 & $\left|\begin{array}{|}\text { 東海 } \\
\text { 北陸 }\end{array}\right|$ & 近畿 & 中国 & 四国 & 九州 & 計 \\
\hline 150 円以下 & 1.4 & 0.9 & 1.3 & 0 & 2.0 & 4.3 & 1.2 & 1.4 \\
\hline 151 180 円 & 0 & 9.3 & 6.6 & 0 & 3.9 & 917.0 & 1.2 & 5.1 \\
\hline $181 \sim 210$ & 11.3 & 28.7 & 17.1 & 8.6 & 3.9 & $\begin{array}{l}9 \\
9\end{array}$ & 9.3 & 14.3 \\
\hline $211 \sim 240$ & 15.5 & $\mid 15.7$ & 6.6 & 25.7 & 11.8 & 38.5 & 19.7 & 15.3 \\
\hline $241 \sim 270$ & 25.4 & 19.4 & 15.8 & 30.0 & 23.5 & 23.4 & 25.6 & 23.0 \\
\hline $271 \sim 300$ & 8.5 & 11.1 & 13.2 & 14.3 & 13.7 & 14.9 & 20.9 & 13.7 \\
\hline $301 \sim 350$ & 9.8 & 1.9 & 17.1 & 4.3 & 13.7 & 4.3 & 7.0 & 7.9 \\
\hline $351 \sim 400$ & 9.8 & 1.9 & 9.2 & 5.7 & 17.7 & 2.1 & 7.0 & 7.1 \\
\hline 401 円以上 & 9.8 & 2.8 & 10.5 & 4.3 & 5.9 & 8.5 & 4.6 & 6.3 \\
\hline 最近購入していない & 8.5 & 8.3 & 2.6 & 7.1 & $|3.9|$ & \begin{tabular}{l|l}
9 & 6.4 \\
\end{tabular} & 3.5 & 5.9 \\
\hline t? & 100 & 100 & 100 & 100 & 100 & 100 & 100 & 100 \\
\hline
\end{tabular}

で購入している人は 50 代で $31.2 \% ， 40$ 代で $21.9 \%$ に対し，30 代で 12.6\%，20 代で 13.2\% となってい る。

〔地域別]にみると，第8 表に示すように関東地区で 目立って購入価格が低く $38.9 \%$ の 人が 210 円以下で購 入して少り, 特に 181 円から 210 円の幅の中で購入し ている人が $28.7 \%$ を占的ている。次いで購入価格の低 いのは四国で 210 円以下で $31.9 \%$ となって亦り，特に 151 円から 180 円の幅の中で購入している人が $17 \%$ あ ることが注目される。

一方，購入価格の高いところは，中国地区，東海・北 陸地区で約 37\% の人が 301 円以上で購入して京り, 次 いで北海道が $29.4 \%$ となっている。なお，購入洒格が 極端に 分散しているのが 東海・北陸地区で 301 円以上 で購入している人が $36.8 \%$ いる反面, 210 円以下で購 入している人が $25 \%$ ある。

\section{2. 消費量 ( 1 人 1 力月)}

1 人 1 カ月の消費量については第 9 表に示すように全 体として，1 1 力月の消費量は， $401 \mathrm{ml} 450 \mathrm{ml}$ の人 が最も多く $14.2 \%$ を占め, 次いで $201 \mathrm{ml} 250 \mathrm{ml}$ が $12.2 \%, 251 \mathrm{ml} \sim 300 \mathrm{ml}, 601 \mathrm{ml}$ 以上が $11.4 \%, 351$ $\mathrm{m} l \sim 400 \mathrm{ml}$ が $11.2 \%, 301 \mathrm{ml} \sim 350 \mathrm{ml}$ が $10.2 \%$ とな
第 9 表 1 人 1 ケ月の消費量

(単位 $=\%$ )

\begin{tabular}{|c|c|c|c|c|c|}
\hline 項目 年代 & 20 代 & 30 代 & 40 代 & 50 代以上 & 計 \\
\hline $200 \mathrm{~m} l$ 以下 & 9.0 & 12.8 & 9.4 & 5.8 & 9.1 \\
\hline $201 \sim 250 \mathrm{~m} l$ & 13.4 & 15.4 & 7.6 & 14.6 & 12.2 \\
\hline $251 \sim 300$ & 16.4 & 12.8 & 12.3 & 6.6 & 11.4 \\
\hline $301 \sim 350$ & 9.0 & 8.6 & 9.9 & 12.4 & 10.2 \\
\hline $351 \sim 400$ & 11.9 & 12.0 & 11.7 & 9.5 & 11.2 \\
\hline $401 \sim 450$ & 10.4 & 17.1 & 14.6 & 12.4 & 14.2 \\
\hline $451 \sim 500$ & 11.9 & 9.4 & 4.7 & 15.3 & 9.5 \\
\hline $501 \sim 550$ & 6.0 & 4.3 & 7.6 & 6.6 & 6.3 \\
\hline $551 \sim 600$ & 1.5 & 3.4 & 7.0 & 3.7 & 4.5 \\
\hline $601 \mathrm{~m} l$ 以上 & 10.5 & 4.3 & 15.2 & 13.1 & 11.4 \\
\hline 計 & 100 & 100 & 100 & 100 & 100 \\
\hline
\end{tabular}

第 10 表 地域的にみた 1 人 1 ケ月消費量

\begin{tabular}{|c|c|c|c|c|c|c|c|c|}
\hline 地域 項目 & 北海道 & 䦔東 & $\begin{array}{l}\text { 東海 } \\
\text { 北陸 }\end{array}$ & 近畿 & 中國 & 匹国 & 九州 & 計 \\
\hline $200 \mathrm{~m} l$ 以下 & 8.8 & 12.2 & 9.2 & 4.4 & 6.1 & 11.1 & 10.3 & 9.2 \\
\hline $201 \sim 250 \mathrm{~m} l$ & 7.4 & 15.9 & 10.5 & 13.0 & 14.3 & 11.1 & 11.5 & 12.2 \\
\hline $251 \sim 300$ & 8.8 & 13.1 & 19.7 & 7.3 & 10.2 & 11.1 & 7.7 & 11.4 \\
\hline $301 \sim 350$ & 7.4 & 10.3 & 14.5 & 8.7 & 14.3 & 6.7 & 9.0 & 10.2 \\
\hline $351 \sim 400$ & 8.8 & 11.2 & 10.5 & 17.4 & 8.2 & 11.1 & 10.3 & 11.2 \\
\hline $401 \sim 450$ & 14.7 & 9.4 & 11.8 & 21.7 & 20.4 & 8.9 & 15.3 & 14.2 \\
\hline $451 \sim 500$ & 17.6 & 8.4 & 11.8 & 5.8 & 6.1 & 6.7 & 9.0 & 9. 5 \\
\hline $501 \sim 550$ & 5.9 & 7.4 & 4. 0 & 5.8 & 2. 0 & 11.1 & 7.7 & 6.3 \\
\hline $551 \sim 600$ & 5.9 & 0.9 & 4.0 & 5.8 & 10.2 & 4.4 & 3. 8 & 4.4 \\
\hline $601 \mathrm{~m} l$ 以上 & 14.7 & 11.2 & 4.0 & 10.1 & 8.2 & 17.8 & 15.4 & 11.4 \\
\hline 部 & 100 & 100 & 100 & 100 & 100 & 100 & 100 & 100 \\
\hline
\end{tabular}

って岕り， $600 \mathrm{ml}$ 以上を除き， $201 \mathrm{~m} l$ から $450 \mathrm{ml}$ まで の間に平均化して多く，約 $60 \%$ の人が占引ている。

[年代別]にみると，1人1 カ月の消費量は 20 代, 30 代で少なく, 40 代, 50 代は多いと云方る。つまり消 費量 $300 \mathrm{ml}$ 以下の人は 30 代では $41 \%, 20$ 代で 38.8 \%を占めているのに比し，40 代は 29.3\%，50 代は $27 \%$ となっている。反面, $501 \mathrm{ml}$ 以上消费する人は 40 代が 29.8\%，50 代が $23.4 \%$ に比し 20 代が $18 \%$, 30 代が $12 \%$ となっている。

〔地域别】にみると，第 10 袁に示すように消費量の少 ないのは, 関東, 東海・北陸地区で, 多いのは四国, 九 州, 北海道・東北地区である。つまり消費量 $300 \mathrm{~m} l$ 以 下で全体方 $33 \%$ にたいし, 聞東地区で $41.2 \%$, 東海・ 北陸地区で 39.4\% となっている。他方, $501 \mathrm{~m} l$ 以上で 全体が $22 \%$ にたいし, 四国が $33.3 \%$, 九州, 北海道・ 東北が約 $27 \%$ と多い。特に, $601 \mathrm{ml}$ のへビーユーザー は四国地区で $17.8 \%$ ，九州，北海道・東北地区で約 15 \%であるのが目立つ。

\section{III. 購入時の選択基準}

購入特の選択基準については第 11 表に示すように全 体としては,「しょう油購入時の際の邆択基準」について 
第 11 表 購入時の選択基準

(単位 $=\%$ )

\begin{tabular}{|c|c|c|c|c|c|}
\hline 項目 年代 & 20 代 & 30 代 & 40 代 & 50 代以上 & 計 \\
\hline 種 & 58.2 & 69.5 & 64.5 & 64.0 & 64.7 \\
\hline ブランド & 32.8 & 38.1 & 37.2 & 40.3 & 37.7 \\
\hline 価 & 34.3 & 21.2 & 20.3 & 20.1 & 22.4 \\
\hline 添加物の有無 & 26.9 & 27.1 & 25.6 & 28.8 & 27.0 \\
\hline 製造年月日 & 34.3 & 33.9 & 29.7 & 29.5 & 31.3 \\
\hline 級 & 22.4 & 22.0 & 29.7 & 38.8 & 29.4 \\
\hline 生産方式 & 9.0 & 18.6 & 20.9 & 34.5 & 22.6 \\
\hline 容器の種類 & 14.9 & 20.3 & 27.3 & 30.2 & 24.8 \\
\hline 特にない & 9.0 & 5.9 & 6.4 & 6.5 & 6.7 \\
\hline そ の 他 & 0 & 0.8 & 0.6 & 0 & 0.4 \\
\hline
\end{tabular}

（注）重複回答のため，合計は100\%にならない。

第 12 表 地域的にみた選択の基箔

(単位 $=\%$ )

\begin{tabular}{|c|c|c|c|c|c|c|c|c|}
\hline 地域 & $\begin{array}{l}\text { 北海道 } \\
\text { 北 }\end{array}$ & 関東 & $\begin{array}{l}\text { 東海 } \\
\text { 北陸 }\end{array}$ & 近畿 & 中国 & 四国 & 九州 & 㖕 \\
\hline 種 & 52.2 & 49.1 & 50.6 & 89.9 & 72.0 & 80.0 & 75.6 & 64.7 \\
\hline ブ & 50.7 & & 39.0 & 37.7 & 3.0 & 31.1 & 2.1 & 37.7 \\
\hline 価 & 24.6 & 27.8 & 20.8 & 23.2 & 0.0 & 8 & .9 & 22.4 \\
\hline 添加物の有無 & 26.1 & 31.5 & 32.5 & 21.7 & 0.0 & 24.4 & 5.9 & 27.0 \\
\hline 製造年月日 & 34.8 & 36.1 & 28.6 & 26.1 & 28.0 & 31.1 & 30.8 & 31.3 \\
\hline & 44 & 24.1 & 22.1 & 6 & 42.0 & 3.6 & 3.1 & 29.4 \\
\hline 生産方式 & 30.4 & 21.3 & 20.8 & 5 & 24.0 & 28.9 & 1.8 & 22. \\
\hline 容器の種類 & 21.7 & 23.1 & 26.0 & 37.7 & 12.0 & 31.1 & 21.8 & 24.8 \\
\hline 特にない & 1.4 & 7.4 & 10.4 & 5.8 & 10.0 & 8.9 & 3.8 & 6.7 \\
\hline その & . & 0.9 & 0 & 0 & 0 & 0 & 1.3 & 0. \\
\hline
\end{tabular}

（注）重䙦回答のため，合計は100\%にならない。

みると,「種類」を基準とする人は, 全体の $65 \%$ を占め 一番多く，「ブランド」を基準とする人は約 $38 \%$ で, 次 に「製造年月日」「等級」「添加物の有無」「容器の種類」 「生産方式」「価格」の順となっている。

[年代別〕にみると，「種類」を基準とする人は各年代 とも平均して多い。 2 番目の選択基準は「ブランド」で あるが，20 代だけ「価格」「製造年月日」を基準として 購入する人が $34 \%$ と多く「ブランド」は 4 番目の迷択 基準となっている。また，40 代，50 代以上は「等級」 「生産方式」「容器の種類」と, 主として品質を重視して いる人が多い。

〔地域別】にみると第 12 表に示すように, 北海道・東 北, 関東, 東海・北陸地区等, いわゆるこいくち地区は 「種類」については関心がうすいようで, 全体の平均值 より少なくなっているが，近畿のらちくち地区と四国地 区は逆に多い。また「ブランド」を基準としている地区 は，北海道・東北地区が多く，「価格」を基準にしている 地区は関東地区に多い。「等級」については, 北海道・東 北, 中国地区が多い。「生産方式」については, 北海道・ 東北, 四国地区が多く,「容器の種類」については, 近 幽, 四国地区が多い。その他の項目については, 各地区 ともたいした変化はみられない。

\section{IV. 消費動向について}

\section{1. 消費量の変化}

消費量の変化については第 13 表に示すよらに, 全体として，1 人当りのしょら油の消費量は $2 \sim 3$ 年 前と比べて「変わらない」が約半分の $47 \%$ となってお

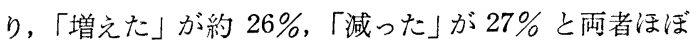
拮抗している。

〔年代別】にみると，1 人当りのしょら油の消費量が $2 \sim 3$ 年前に比べて「変わらない」のは各年代とも平均 して約半分程度であるが，この中で 30 代だけが「増え た」(44\%)という動きをしているのが目立つ。一方もと もと消費量の多い 40 代, 50 代 (II-2 参照) では 3 人 に1人「減った」としている。

〔地域別】にみると第 14 表に示すように，1 人当りの 消費量が増えている地区は, 消費量の多かった近畿, 四 国地区で, また一方, 減っているのも消費量の多かった 中国，北海道・東北地区となっている。

\section{2. 增えた理由}

消費量の増えた理由としては第 15 表に示すように全 体として，1 人当りの消費量が $2 \sim 3$ 年前に比べて「増 えた理由」としての主なものは，「子供が成長し，たく さん使うようになった」が $68.3 \%$ と一番多く, 次いで

第 13 表 消費量の変化

\begin{tabular}{|c|c|c|c|c|c|}
\hline \multicolumn{6}{|c|}{ (単位 $=\%$ ) } \\
\hline 項目 算代 & 20 代 & 30 代 & 40 代 & 50 代以上 & 計 \\
\hline 增えた & 22.3 & 44.4 & 17.0 & 18.2 & 25.8 \\
\hline 減った & 13.9 & 15.6 & 32.2 & 35.8 & 26.8 \\
\hline 変わらない & 53.8 & 40.0 & 50.8 & 46.0 & 47.4 \\
\hline 計 & 100 & 100 & 100 & 100 & 100 \\
\hline
\end{tabular}

第 14 表 地域的に見た消費量の変化

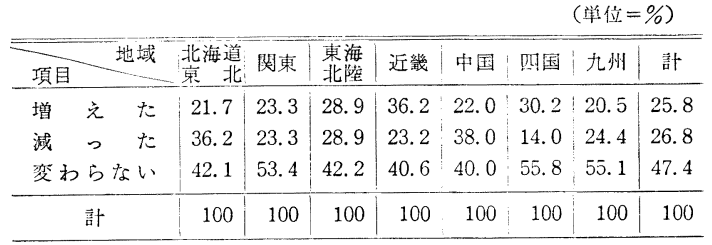

第 15 表 消費量の増えた理由

(単位 $=\%)$

\begin{tabular}{|c|c|c|c|c|c|}
\hline 項目 年代 & 20 代 & 30 代 & 40 代 & 50 代以上 & 計 \\
\hline 子供が成铭したから & 52.4 & 86.3 & 72.4 & 40.0 & 68.3 \\
\hline しょう油料理を好むから & 42.9 & 33.3 & 37.9 & 44.0 & 38.1 \\
\hline 和風に変ったから & 19. 0 & 9.8 & 27.6 & 20.0 & 17.5 \\
\hline 家庭料理が增えたから & 19.0 & 11.8 & 13.8 & 8.0 & 12.7 \\
\hline 調理が手㪕だから & 23.8 & 15.7 & 20.7 & 16.0 & 18.3 \\
\hline 経済的だから & 0 & 7.8 & 6.9 & 20.0 & 8.7 \\
\hline その 他 & 4.8 & 5.9 & 10.3 & 12.0 & 7.9 \\
\hline
\end{tabular}

（注）重複回答のため，合計は100\%にならない。 
第 16 表 地域的にみた増えた理由

(単位 $=\%$ )

\begin{tabular}{|c|c|c|c|c|c|c|c|c|}
\hline 地域 & $\begin{array}{l}\text { 北海道 } \\
\text { 東 北 }\end{array}$ & 関東 & $\begin{array}{l}\text { 東海 } \\
\text { 北陸 }\end{array}$ & 近畿 & 中国 & 回国 & 九州 & 計 \\
\hline 子供が成長したから & 80.0 & 62.5 & 45.5 & 72.0 & 72.7 & 69.2 & 87.5 & 68.3 \\
\hline しょう油料理を好むから & 20.0 & 37.5 & 45.5 & 44.0 & 27.3 & 46.2 & 37.5 & 38.1 \\
\hline 和風に変ったから & 6.7 & 29.2 & 27.3 & 16.0 & 9.1 & 7.7 & 12.5 & 17.5 \\
\hline 家庭料理が増えたから & 0 & 25.0 & 9.1 & 16.0 & 0 & 7.7 & 18.8 & 12.7 \\
\hline 調理が手軽たから & 26.7 & 33.3 & 13.6 & 16.0 & 9.1 & 7.7 & 12.5 & 18.3 \\
\hline 経済的だから & 13.3 & 0 & 9.1 & 8.0 & 0 & 30.8 & 6.3 & 8.7 \\
\hline その 他 & 6.7 & 8.3 & 9.1 & 4.0 & 0 & 23.1 & 6.3 & 7.9 \\
\hline
\end{tabular}

（注）重複回答のため，合計は100\%にならない。

第 17 表 使用量が減った理由

(単位 $=\%$ )

\begin{tabular}{|c|c|c|c|c|c|}
\hline 項 目 年 代 & 20 代 & 30 代 & 40 代 & $\begin{array}{l}50 \text { 代 } \\
\text { 以上 }\end{array}$ & 計 \\
\hline 洋食に変ったから & 55.6 & 55.6 & 30.9 & 36.7 & 38.2 \\
\hline 家庭料理が減ったから & 11.1 & 22.2 & 14.5 & 4.1 & 11.5 \\
\hline 塩分を控えたから & 55.6 & 61.1 & 61.8 & 75.5 & 66.4 \\
\hline しょら油料理を好まないから & 0 & 11.1 & 1.8 & 4.1 & 3.8 \\
\hline しょら油料理は面倒たから & 0 & 5.6 & 1.8 & 0 & 1.5 \\
\hline その他 & 0 & 5.6 & 14.5 & 18.4 & 13.7 \\
\hline
\end{tabular}

（注）重複回答の心や合計は100\%にならない。

「しょら油料理を好むようになったから」38.1\%，「しょ ら油を使った料理は調理が手軽だから」18.3\%,「食生 活の様式が洋風から和風に変ったから」17.5\%,「外食 や調理済の食品の購入を減らし家庭での調理が増えたか ら」 $12.7 \%$ の順となっている。

増えた「その他」の理由としては，「家族が増えたか ら」「煮物料理が增光たから」「他の調味料の代わりに使 らよらになったから」「つくだ煮の常備食を作るよらに なったから」等であった。

〔年代別】にみると,「子供が成長したから」增えたと する人は, 30 代, 40 代に多く, いわゆる成長期の子供 を持つ年代層に多く，20 代，50 代は平均より少ない。 「しょら油料理を好むようになったから」増えたとする 人は 20 代と 50 代汇多く, 「食生活の様式が洋風から和 風に変ったから」增えたのは 40 代に多く,「しょら油を 使った料理は経済的だから」増えたのは，50 代以上に 多小。

〔地域別】にみると，第 16 表に示すように「子供が成 長したから，たくさん使らよらになった」のは家族構成 の変化によるものであろら。

「しょら油料理を好むようになったから増えた」とす るのは, 東海・北陸, 近畿, 四国地区で, 少ないのは北 海道・東北地区である。

「調理が手軽だから増えた」とするのは，北海道・東 北, 関東地区が多く、「和風に変ったから増えた」とす るのは, 関東, 東海・北陸地区に多い。また「家庭料理 が増えたから」とするのは, 関東, 九州地区が多く、 「経済的だから」とするのは，四国地区に多い。
第 18 表 地域的にみた使用量が減った理由

(単位 $=\%$ )

\begin{tabular}{|c|c|c|c|c|c|c|c|c|}
\hline 項目 地域 & 北海道 & 関東 & $\mid \begin{array}{l}\text { 東海 } \\
\text { 北陸 }\end{array}$ & 近畿 & 中国 & 四国 & 九州 & 計 \\
\hline 洋風に変ったから & 36.0 & 33.3 & 27.3 & 68.8 & 42.1 & 33.3 & 31.6 & 38.2 \\
\hline 家庭料理が減ったから & 8.0 & 8.3 & 9.1 & 12.5 & 15.8 & 16.7 & 15.8 & 11.5 \\
\hline 塩分を控えたから & 8.4 & 70.8 & 59.1 & 50.0 & 52.6 & 66.7 & 73.7 & 66.4 \\
\hline $\begin{array}{l}\text { しょう油料理を好まな } \\
\text { いから }\end{array}$ & 0 & 0 & 4.5 & 0 & 15.8 & 0 & 5.3 & 3.8 \\
\hline しょう油料理は面倒た & 0 & 0 & 4.5 & 0 & 5.3 & 0 & 0 & 1.5 \\
\hline その 他 & 20.0 & 8.3 & 31.8 & 0 & 5.3 & 0 & 15.8 & 13.7 \\
\hline
\end{tabular}

（注）重複回答のため，合計は100\%にならない。

第 19 表 今後の消費動向

\begin{tabular}{|c|c|c|c|c|c|}
\hline 項目 年代 & 20 代 & 30 代 & 40 代 & 50 代以上 & 計 \\
\hline 変えよらと思わない & 79.1 & 73.3 & 78.2 & 76.1 & 76.5 \\
\hline 増やしたいと思う & 6.0 & 5.2 & 6.9 & 5.8 & 6.1 \\
\hline 減らしたいと思う & 6.0 & 8.6 & 4.6 & 12.3 & 7.9 \\
\hline わからない & 8.9 & 12.9 & 10.3 & 5.8 & 9.5 \\
\hline 計 & 100 & 100 & 100 & 100 & 100 \\
\hline
\end{tabular}

\section{3. 減った理由}

使用量が減った理由については第 17 表に示すように 全体として，1 人当りの消費量が $2 \sim 3$ 年前に 比べて 「減った理由」としての主なものは，「塩分の恸取量を控 えたいから」が $66.4 \%$ と一番多く, 次いで「食生活の 様式が和風から洋風に変ったから」38.2\%,「外食や調 理済食品の購入が増光家庭での調理が減ったから」 11.5 \%,「しょう油を使った料理を好をなくなったから」3.8 \%,「しょう油を使った料理は調理が面倒だから」1.5\% の順となっている。

減った「その他」の理由としては，「家族が減った」 「めんつゆが便利で，その使用が多くなった」「煮魚をし なくなった」「無䭾な使い方をしなくなった」等であっ た。

[年代別〕にみると，「塩分の摂取量を控えたいから」 減ったとする人は高年㯝層に多く，低年令層ほど少な い。「食生活の様式が和風から洋風に変ったから」減っ たとする人は，20 代，30 代に多く，「家庭での調理が減 った」ので少なくなったとする人は 30 代が目立って多 く，「しょら油を使った料理を好まなくなったから」「し ょう油を使った料理は面倒だから」減ったとする年代も 同じく30 代で多い。

〔地域別】にみると第 18 表に示すよらに,「塩分の摂取 を控えたいから」減ったとする地区は，「減った理由」の 中では各地区とも多いが，北海道・東北地区が極端に少 ないのが目立っている。「食生活の様式が和風から洋風 に変ったから」減ったとする地区は，近畿地区が多く， 「家庭料理が減った」ため少なくなった地区は, 近畿を中 心に東が少なく西が多い。 
第 20 表 地域別にみた今後の消費動问

(単位 $=\%$ )

\begin{tabular}{|c|c|c|c|c|c|c|c|c|}
\hline ……… 域 & $\begin{array}{l}\text { 北海道 } \\
\text { 東 北 }\end{array}$ & 関東 & $\mid$\begin{tabular}{|}
$\mid$ 東海 \\
北陸
\end{tabular} & 近戴 & 中国 & 四国 & 九州 & 計 \\
\hline 変えようと思わない & 81.4 & 72.9 & 76.6 & 73.9 & 76.0 & 88.6 & 73.1 & 76.5 \\
\hline 增やしたいと思う & 7.1 & 7.5 & 5.2 & 7.3 & 4.0 & 6.8 & 3.9 & 6.1 \\
\hline 滅らしたいと思う & 8.6 & 11.2 & 6.5 & 4.3 & 8.0 & 0 & 11.5 & 7.9 \\
\hline わからない & 2.9 & 8.4 & 11.7 & 14.5 & 12.0 & 4.6 & 11.5 & 9.5 \\
\hline 計 & 100 & 100 & 100 & 100 & 100 & 100 & 100 & 100 \\
\hline
\end{tabular}

\section{4. 今後の消費動向}

今後に抢汁るしょう油の消費量の変化については第 19 表に示すように「変えようとは思わない」とするの
が，76.5\% と全体の約 4 分の 3 を占めており，「增やし たいと思う」は $6.1 \%$ また「減らしたいと思う」は 7.9\% で，「わからない」 9.5\% となっている。

〔年代別】にみても，全体の傾向と大差はないが，ただ 50 代で「減らしたいと思う」という層が他の年代に比べ てやや多いようである。

〔地域別】にみると，第 20 表に示すように，これも全 体的傾向と大差はないが, 関東地区と九州地区で「減ら したいと思う」と云う層がやや多いようである。

(日本徆油協会)

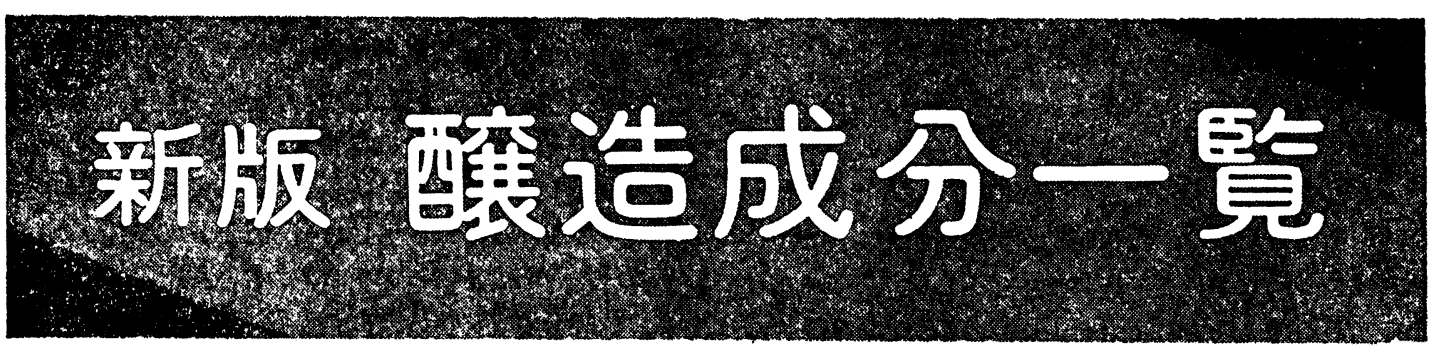

B 5 版 /382 頁/定 価 4,000 円/荷送料 400 円

醉造物中の成分は，これまでに相当数解明されております。研究者は，これらの物質について詳細な 知識を持つ必要がありますが，膨大な数だけに，それは至難なことと申さねばなりません。

そこで, 本会では先に醸造成分一覧（清酒・味嘫・醬油編）を発行して多くの方々に御活用いたたき ましたが今回媇たにブドウ酒・ウィスキー及びブランデー・みりん，それにビール・媌酎の 5 編を加 え新版を刊行することといたしました。

本書には，これまでに判明した成分を全べて収録したほか，嗜好食品の複雑微妙な美味との関係，醇 造物中に存在する成分とその由来, 分析法, 研究の歴史, それに新たな文献の追加等々を行い, これら を容易に一覧できるよう編集し直しました。

研究者の座右の書として, ぜひ一冊和備苀下さい。

\section{(財)日本醀造協会 \\ 114 東京都北区滝野川 2-6 \\ TE L03（910）3853 振替 東京 4-1995 番}

